\title{
Disease, insect pressures make organic production risky in Sonoma County
}

\author{
Paul Vossen $\square$ Desmond Jolly $\square$ Roland Meyer $\square$ Lucia Varela $\square$ Sue Blodgett
}

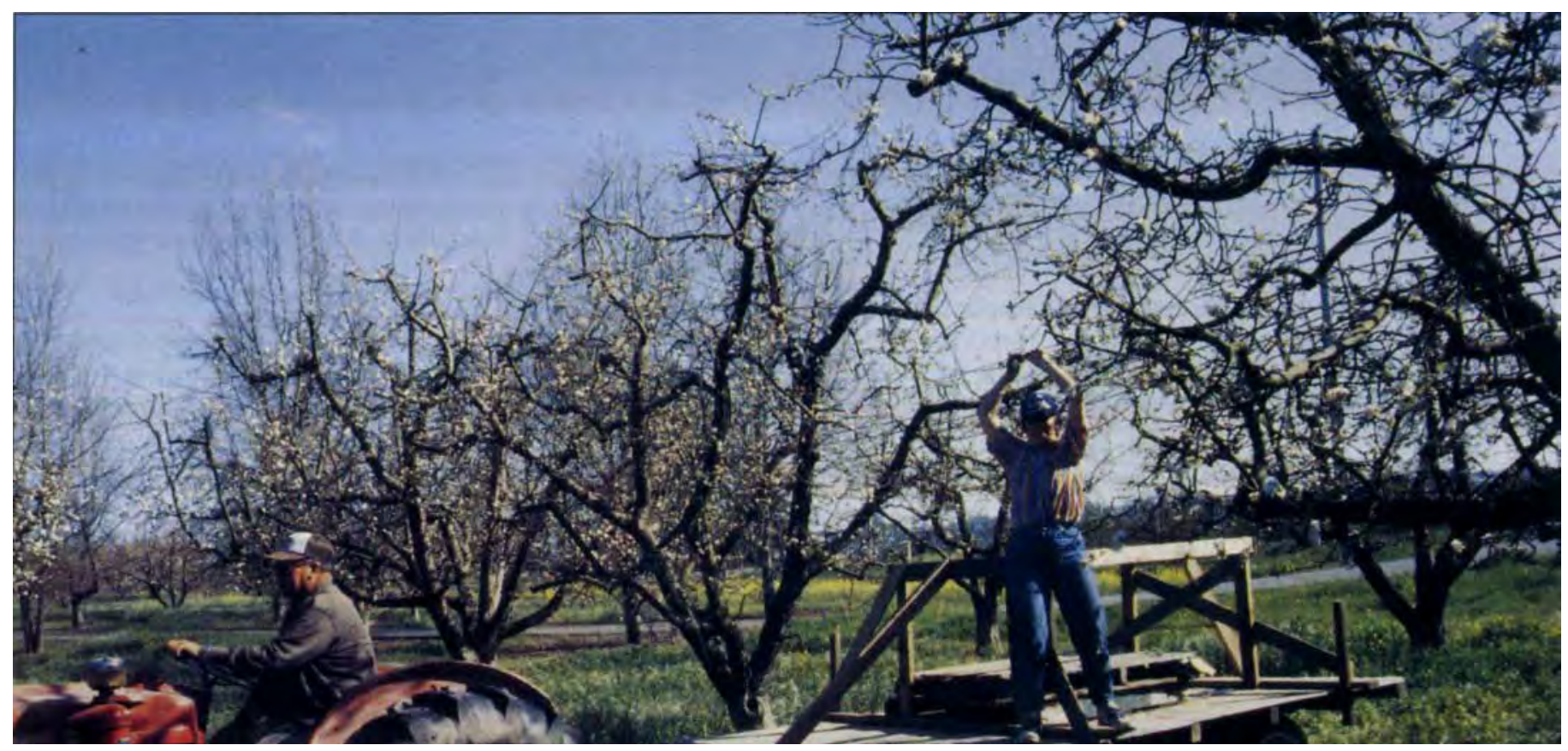

\section{Apple growers are interested in} organic production to take advantage of higher market prices while reducing pesticide inputs. In a Sonoma County study, it was relatively easy and comparable in cost to maintain good tree vigor organically. However, severe insect and disease problems greatly reduced the yield and market value of organic apples compared to conventionally grown apples. The organic production system was also more expensive and more complicated to manage, creating greater risk for the grower. Although organically grown fruit could be sold at higher prices, the price differential was not sufficient to justify the losses, the need for increased management and the additional risk involved.
A systems approach was established to compare the components of organic and conventional apple production systems, including tree growth, yield and fruit quality; biological and chemical nutrient supply systems; disease and insect pest damage; and economic performance for 4 years, 1990 through 1993.

We established conventionally and organically treated plots in a dryfarmed apple orchard (Graton, CA) and replicated them four times. Plot sizes ranged between 1.5 and 2.2 acres. Total acreage was 7.5 for organic treatments and $\mathbf{8 . 2}$ for conventional treatments. Trees were planted in 1964 on 21-feet-by-24-feet spacing. Half the plots were alternate rows of Golden Delicious and Gravenstein; the other half were Red Delicious. The organic growing methods were chosen to meet current standards for certification
Conventionally and organically treated plots were established in a dry-farmed apple orchard in Graton. The plots contained Golden Delicious, Gravenstein and Red Delicious. Sue Blodgett hangs pheromone dispensers for codiling moth control in both plots.

from the California Certified Organic Farmers (CCOF) association. Conventional practices were those chosen by the grower (table 1).

\section{Fertility management practices}

The soil type in this orchard was classified as a Goldridge fine sandy loam, which is a well-drained 60-inchdeep soil, underlain by a clay loam subsoil and sandstone. The organic system received an annual spring application of 2 tons per acre of compost, equivalent to $52,35,39$ and 30 pounds per acre of nitrogen for 1990, 1991, 1992 and 1993 respectively. Total phosphorous $\left(\mathrm{P}_{2} \mathrm{O}_{5}\right)$ additions were $47,66,53$ and 48 pounds per acre, and 
potassium $\left(\mathrm{K}_{2} \mathrm{O}\right)$ was $53,34,43$ and 43 pounds per acre for those same years.

The organic system also incorporated a bell bean/vetch mixed cover crop. Additions of total nitrogen from the bell bean/vetch legume planting, based on aboveground biomass measurements, were from 0 to 30 pounds per acre greater than the conventional plots having resident vegetation containing 25 to 40 pounds of nitrogen per acre. A supplemental application of kelp and fish meal (Mermaid--12\% N, $0.5 \% \mathrm{P}_{2} \mathrm{O}_{5}, 10 \% \mathrm{~K}_{2} \mathrm{O}$ ) was foliar applied the first 3 years at a rate of 4 pounds per acre.

In 1990 and 1991 the conventional system received annual spring applications of granular calcium nitrate at a rate of 100 pounds of nitrogen per acre. In 1992 the same rate of ammonium nitrate was applied. No fertilizer was applied in 1993 because of high tissue levels of nitrogen. Two or three applications of foliar chelated micronutrients, at low rates, were made each year, including boron, zinc, copper, iron and molybdenum. Calcium was included in the foliar mixture at a rate of 2.6 pounds per acre per year to prevent bitter pit. No phosphorus $\left(\mathrm{P}_{2} \mathrm{O}_{5}\right)$ or potassium $\left(\mathrm{K}_{2} \mathrm{O}\right)$ was applied in this system.
We took leaf samples from two nine-tree subplots on a monthly basis from May through October during 1990 and 1991, and three times per year (May, July and September) in 1992 and 1993. Nutrient concentrations were determined for nitrogen $(\mathrm{N})$, phosphorus $(\mathrm{P})$, potassium $(\mathrm{K})$, calcium $(\mathrm{Ca})$, magnesium $(\mathrm{Mg})$, sulfur $(\mathrm{S})$, zinc $(\mathrm{Zn})$, iron $(\mathrm{Fe})$, manganese $(\mathrm{Mn})$, copper $(\mathrm{Cu})$ and boron $(\mathrm{B})$ in 1990 and 1991; in 1992 and 1993 only $\mathrm{N}, \mathrm{Ca}, \mathrm{Zn}$ and $\mathrm{B}$ concentrations were determined. Soil samples consisting of 12 cores from each of the same two nine-tree subplots were collected from depths of 0 to 6 inches, 6 to 12 inches, and 12 to 18 inches in April and May of 1991; April, May and June of 1992; and April of 1993. Total nitrogen, $\mathrm{NH}_{4}-\mathrm{N}$ and $\mathrm{NO}_{3}-\mathrm{N}$ were determined. Apple fruit samples were also analyzed for N-P-K to determine nutrient removal by the crop.

\section{Fruit size management}

Hand-thinning was conducted in the organic system in 1990 and 1992 on the Gravenstein and Golden Delicious varieties and on the Red Delicious in 1990 only, due to heavy fruit set. This was done from mid-May to early June, when fruit size ranged from 0.5 to 1.0

\begin{tabular}{lll}
\multicolumn{2}{c}{ TABLE 1. Annual management practices (treatments) comparing the organic } \\
and conventional systems*
\end{tabular}




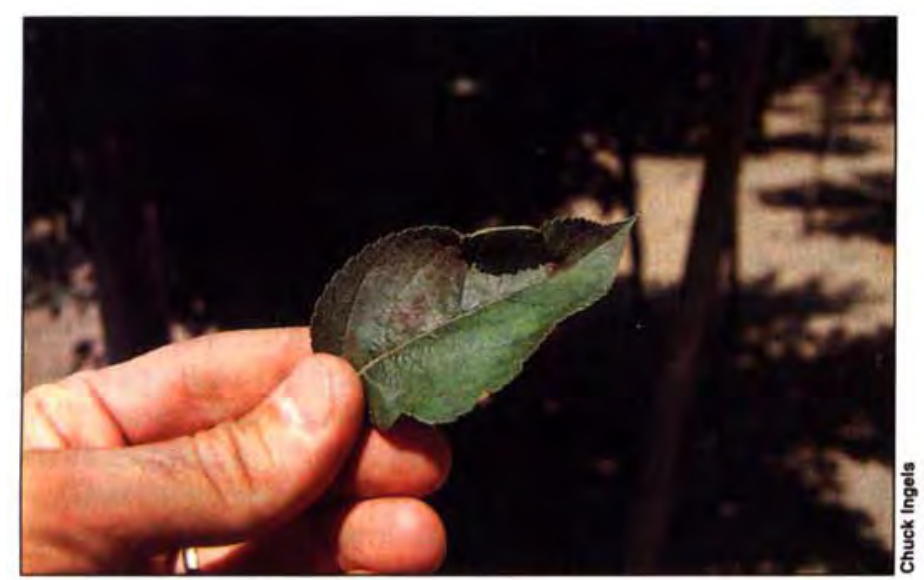

Clockwise from above: Overall damage due to apple scab was $86 \%$ higher in the organic system. Scab lesions damaged fruit, contributing to yield losses. Checking under a cardboard band wrapped around the tree trunk was one way of monitoring codling moths. Organically grown apples, like this Golden Delicious, suffered more codling moth damage.

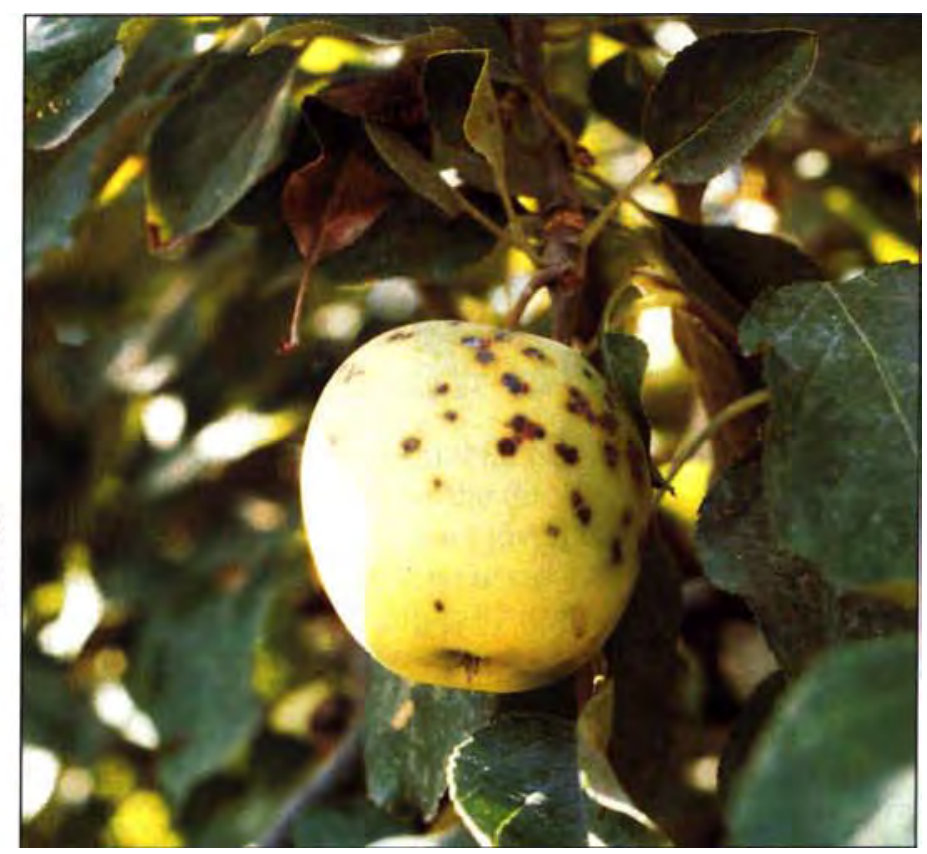

phosmet (Imidan 5 pounds per acre), once in May and again in late June.

In 1992 and 1993, both the organic and the conventional plots were treated with Isomate $\mathrm{C}$ (pheromone confusion dispensers) at a rate of 400 per acre. The dispensers were applied twice, 90 days apart, in the upper third of the tree canopy. The organic plots received two or three supplemental applications of granulosis virus, while the conventional plots received one supplemental application of phosmet during the second generation at the previously stated rates.

As a control, we monitored an abandoned orchard of Golden Delicious and Rome Beauty apples located 100 yards from the organic and conventional plots. The abandoned orchard was disked in the late spring each year to retain soil moisture, but was not fertilized or sprayed with any pesticides.

Spray applications for the organic and conventional plots were made with an air blast (Metters 500 gallon), which delivered 100 gallons per acre.

Codling moth damage was assessed twice during the season, at the end of the first generation and at harvest. Damage from the first codling moth generation was assessed by sampling 1,000 fruit per plot (10 fruit from the top and 10 from the bottom of each of 50 trees). Damage at harvest was assessed by randomly picking 1,000 apples of each variety by plot at maturity. Fruit were visually inspected and classified as clean or codling moth damaged. A sample of 100 clean fruit was then cut open to detect interior codling moth damage not observed from the exterior of the fruit. Damage due to leafrollers, scab, russeting and bitter pit was also recorded at harvest. A sample of 200 fruit per plot of Golden Delicious was also placed in cold storage $\left(33^{\circ} \mathrm{F}\right)$ for 2 months and evaluated for bitter pit.

We estimated yields by measuring fruit weight from nine trees in each plot in 1990 and from the total number of bins from 1990 to 1993 . Yields were measured in two ways in 1990 to verify the bin method. Soluble solids and fruit size were measured for $\mathbf{1 0 0}$ randomly selected fruit in each plot. Shoot length was measured at random from 10 shoots from 10 trees per plot; trunk diameters were taken from those same 10 trees each year in January.

On-site temperature data were collected using a 7-day recording thermograph. These data were used to run the BUGOFF2 codling moth phenology/prediction model and to compute degree-day accumulation. Adult male moths were monitored with pherocon $C$ traps (Trece Inc., Salinas, CA) containing $1 \mathrm{mg}$ lures, one trap per plot.

Per-acre costs were based on data supplied by the cooperating grower by
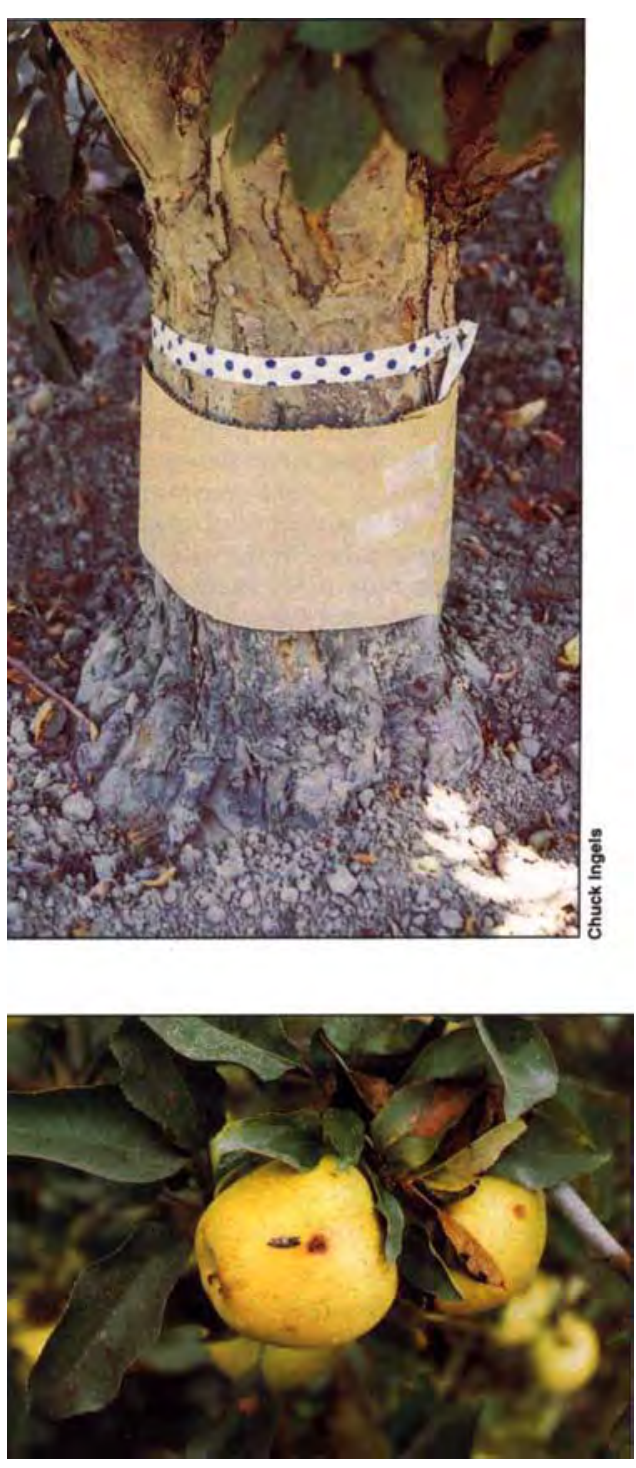

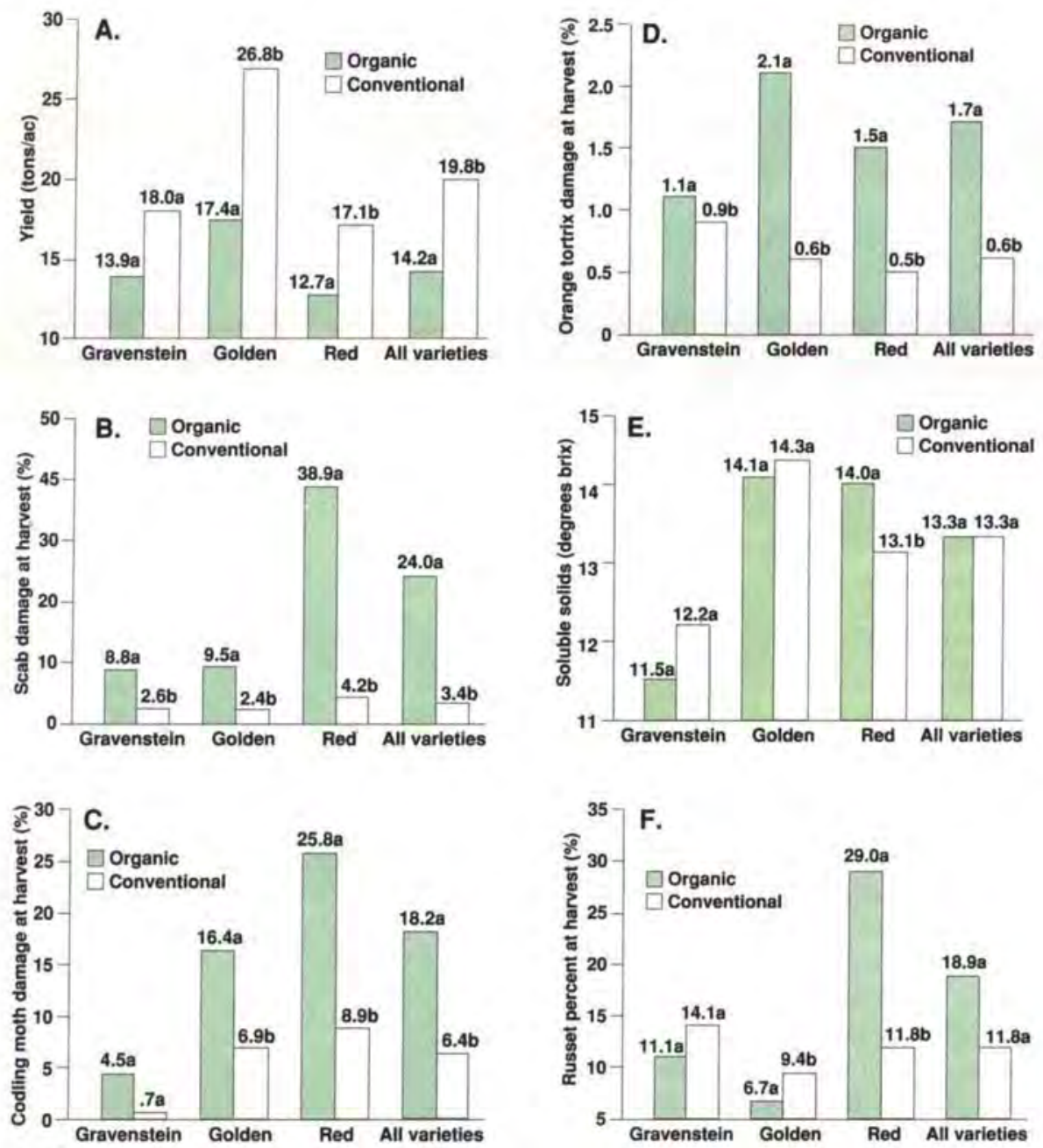

Fig. 1. Comparison of organic and conventional apple production systems, from 1990 to 1993. Graphs depict significant differences in (A) yield in tons/ac, (B) scab percent damage at harvest, (C) codling moth percent damage at harvest, (D) orange tortrix percent damage at harvest, $(E)$ soluble solids and $(F)$ russet percent damage at harvest. There were no significant differences in trunk diameter, shoot length, fruit size or bitter pit percent damage at harvest (data not shown). Numbers followed by different letters in each pair of columns were significantly different at $P=0.5$

listing all operations: time to perform pest control procedures, hours of labor, equipment used and materials applied for each plot separately.

Data were analyzed using ANOVA by variety and by plot. When data for "all varieties" are given, they are calculated by combining the Gravenstein and Golden Delicious since these varieties were interplanted.

\section{Mating disruption trial}

Pheromone dispensers were applied to four different orchards in Sonoma County during 1990 through 1993. Five-acre plots were used to evaluate the pheromone products. The dispenser used was Checkmate CM (Consep, Bend, Oregon). Three appli- cations of Checkmate $\mathrm{CM}$ dispensers, 60 days apart, were placed at a height of 6 to 8 feet on the tree at the rate of 120 dispensers per acre.

Two of the locations had a comparable-size plot treated with azinophosmethyl (Guthion, 2 applications), the third was treated with phosmet (Imidan, 2 applications), and the fourth was organically treated with two applications of summer oil during the first generation and one application of ryania (Ryan 50) plus two applications of codling moth granulosis virus during the second generation. At all the locations 15 to 30 trees were used as the control and not treated. Control trees were approximately 100 yards from the pheromone-treated plots. Codling moth damage was assessed after the first generation and at harvest as described.

\section{Yield, pest damage}

Over a 4-year period (1990-1993), the organic system yielded approximately $40 \%$ less than the conventional system. There was a significant difference in yield for all varieties; the organic system produced 14.2 tons per acre, and the conventional system 19.8 tons per acre (fig. 1A). In 3 out of 4 years the organic system yields were lower for all three varieties. The worst year was 1993, when per-acre yield was 1.3 tons in the organic system compared to 3.4 tons in the conventional system for Gravenstein; 6.8 tons in the organic system compared to 21.0 in the conventional system for Golden Delicious, and 5.3 tons in the organic system compared to 10.6 in the conventional system for Red Delicious. In 1992, however, yields were almost equal in the two systems for Gravenstein and Golden Delicious; and in 1990 the Red Delicious yield was slightly higher in the organic system.

Most of the yield loss was attributable to early season scab Venturia innequalis infection, which caused blossom drop. Scab lesions at harvest were also significantly more numerous, with $24 \%$ of the fruit damaged in the organic system and $3.4 \%$ in the conventional system for all 4 years and all varieties combined (fig. 1B). In years with wet spring weather, the organically treated Red Delicious sustained the most damage. In 1992 and 1993 the organic Red Delicious had $87.9 \%$ and $56.5 \%$ damage, compared with $6.1 \%$ and $7.9 \%$ for the conventional system. In 1990 and 1991, years with drier spring weather, the organic Red Delicious had $2.4 \%$ and $9.0 \%$ damage, compared with $0.4 \%$ and $2.5 \%$ for the conventional, bringing the 4-year average down. Overall damage due to scab was $86 \%$ higher in the organic system.

Codling moth (Cydia [Laspeyresia] pomonella) damage levels for all varieties at harvest were $18.2 \%$ in the organic system and $6.4 \%$ in the conventional system (fig. 1C). There were significant differences in codling moth damage among all varieties, and some 
variation in the amount of damage between plots, but overall codling moth damage was $65 \%$ higher in the organic system. Gravenstein apples, which are picked early in the season, sustained the least damage. Codling moth levels in the nearby abandoned orchard used as the control showed a 53 to $70 \%$ infestation rate, depending on the year. This rate is similar to that in other untreated orchards in the area.

There were significant differences in orange tortrix (Argyrotaenia citrana, Fernald) damage for all varieties combined and for the Gravenstein and Golden Delicious (fig. 1D). There was also considerable variation in the orange tortrix damage level from year to year in the Red Delicious variety (data not shown). Overall orange tortrix damage was $68 \%$ higher in the organic system. Damage due to orange tortrix ranged from 1.1 to $2.1 \%$ in the organic plots and from 0.5 to $0.9 \%$ in the conventional plots.

\section{Codling moth damage}

Codling moth caused more damage in the pheromone confusion plots than in the insecticide-treated plots (table 2). Damage ranged from 0.1 to $29.9 \%$ in the organic plots, and from 0 to $10 \%$ in the conventional insecticide plots. All sites were under high codling moth population pressure. Damage in the untreated orchards ranged from 4.3 to $49.9 \%$. Site A sustained less damage than the other sites in the plots under pheromone confusion. This site is cooler than the other sites (it accumulated 300 to 400 fewer degreedays per growing season than the warmer locations).

Checkmate dispensers have two release membranes, one for cooler weather and one for warmer weather. It is possible that Checkmate is more effective under cooler conditions. In orchards where we have data for 3 to 4 years, we observed an incremental increase in codling moth damage in each successive year, corresponding with a buildup in population.

\section{Soil fertility, plant nutrition}

Both organically and conventionally treated plots had leaf concentrations within or above the adequate range for all nutrients. Leaf-tissue analyses of the July samples are given in table 3. In 1990 the conventionally treated plots had significantly higher $\mathrm{N}, \mathrm{P}, \mathrm{Zn}, \mathrm{Fe}, \mathrm{Mn}, \mathrm{Cu}$ and $\mathrm{B}$ concentrations. Monthly leaf samples, taken in April through October of 1990, indicated significantly higher $\mathrm{N}, \mathrm{Ca}, \mathrm{Zn}$, $\mathrm{Cu}$ and $\mathrm{B}$ concentrations in much or part of the year for the conventional plots. Only $\mathrm{P}, \mathrm{Zn}$ and $\mathrm{Cu}$ were significantly higher in 1991, but monthly samples indicated slightly higher (some significant) levels of $\mathrm{N}, \mathrm{P}, \mathrm{Ca}$,
$\mathrm{Zn}$ and $\mathrm{Cu}$, and lower $\mathrm{S}$ concentrations, for the conventional plots. Both organic and conventional nutrient concentrations were within or above the adequate range. Leaf-tissue levels in 1992 and 1993 were similar for N, Ca and $B$, but had a higher $\mathrm{Zn}$ concentration in the conventionally treated plots.

Soil total $\mathrm{N}, \mathrm{NH}_{4}-\mathrm{N}$ and $\mathrm{NO}_{3}-\mathrm{N}$ levels for the three depths and six sample dates are given in table 4 . Concentrations were essentially the same for the organically and conventionally treated

TABLE 2. Codling moth damage at harvest in four orchards in Sonoma County under pheromone mating disruption, insecticide control, or organic control, and untreated

\begin{tabular}{|c|c|c|c|c|c|c|c|c|c|}
\hline \multirow[b]{2}{*}{ Site } & \multirow[b]{2}{*}{ Treatment } & \multicolumn{4}{|c|}{$\%$ codling moth damage } & \multicolumn{4}{|c|}{ No. of codling moths/trap/year } \\
\hline & & 1990 & 1991 & 1992 & 1993 & 1990 & 1991 & 1992 & 1993 \\
\hline \multirow[t]{3}{*}{ A } & Pheromone & 1.9 & 0.1 & 1.0 & 3.8 & 3 & 3 & 2 & 1 \\
\hline & Insecticide & 0.5 & 0.1 & 0.0 & 0.6 & 178 & 128 & 129 & 134 \\
\hline & Untreated & 36.0 & 5.6 & 4.9 & 20.2 & 241 & 165 & 199 & 150 \\
\hline \multirow[t]{3}{*}{ B } & Pheromone & - & 21.0 & - & - & - & 1 & - & - \\
\hline & Organic & - & 25.2 & - & - & - & 260 & - & - \\
\hline & Untreated & - & 21.7 & - & - & - & 353 & - & 一 \\
\hline \multirow[t]{3}{*}{ C } & Pheromone & - & 4.2 & 1.1 & 29.9 & - & 14 & 164 & 90 \\
\hline & Insecticide & - & 0.1 & 0.6 & 10.0 & - & 82 & 193 & 218 \\
\hline & Untreated & - & 15.0 & 4.3 & - & - & 86 & 225 & 282 \\
\hline \multirow[t]{3}{*}{ D } & Pheromone & - & - & 27.1 & 12.9 & - & - & 18 & 44 \\
\hline & Insecticide & - & - & 4.3 & 2.1 & - & - & 165 & 169 \\
\hline & Untreated & - & - & 49.9 & 34.5 & - & - & 227 & 338 \\
\hline
\end{tabular}

$\begin{array}{r}\text { TABLE 3. Apple leaf tissue nutrient concentrations in early July } \\ \text { for conventional and organically managed orchards } \\ \text { (average of two subsamples per replication and four replications) } \\ \hline \hline\end{array}$

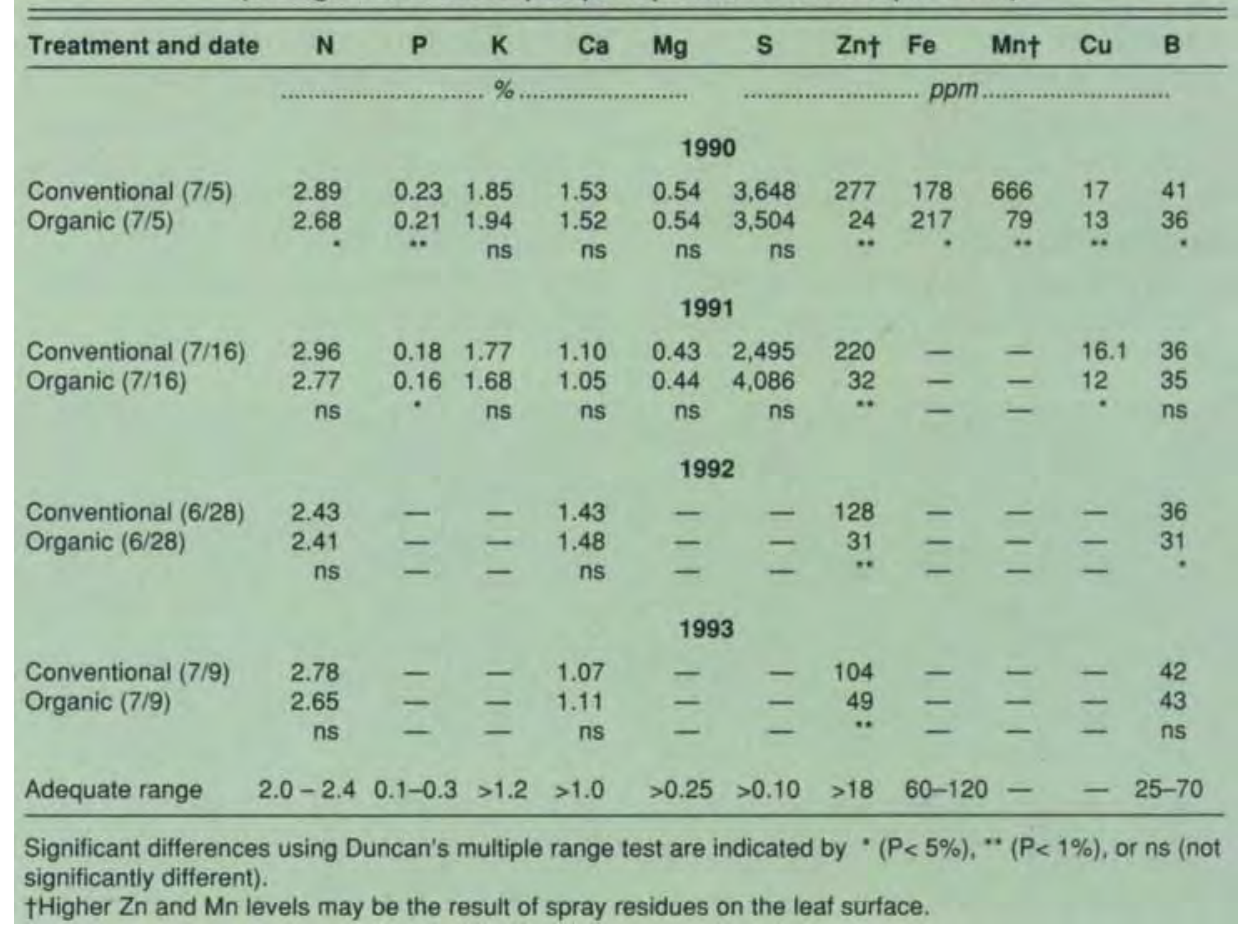




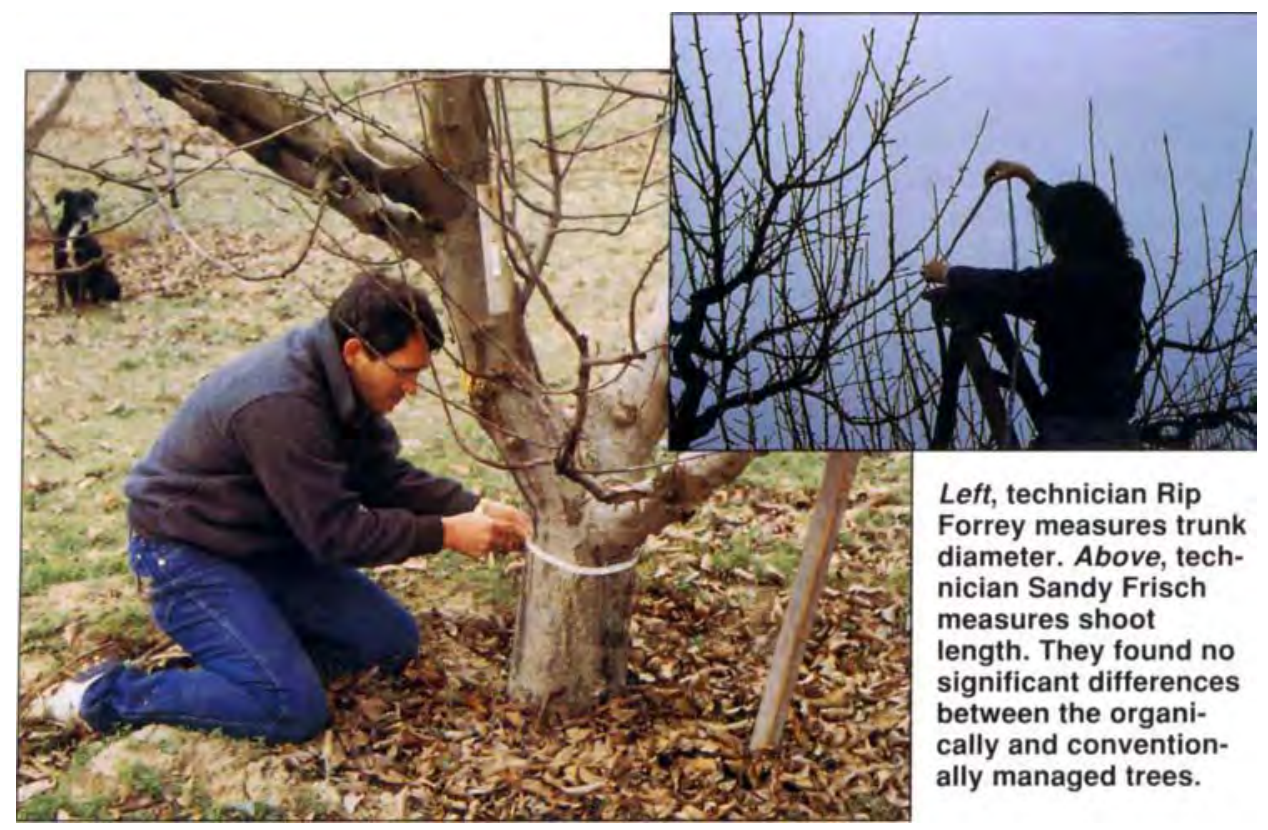

plots. The data suggest a possible weak trend during 1992, when the organic plots had slightly higher $\mathrm{NH}_{4}-\mathrm{N}$ and slightly lower $\mathrm{NO}_{3}-\mathrm{N}$ concentrations than the conventional plots.

Fertility maintenance is fairly easy to achieve in both organically grown and conventionally grown apples because the annual nutrient removal by the fruit is fairly low. Nutrient removal by the fruit in a 20-ton crop was 29,4 and 56 pounds per acre of nitrogen, phosphorus $\left(\mathrm{P}_{2} \mathrm{O}_{5}\right)$ and potassium $\left(\mathrm{K}_{2} \mathrm{O}\right)$ respectively, based on laboratory analyses performed on apple samples. Soil levels of phosphorus and potassium were adequate to supply the above-mentioned nutrient removals, plus those necessary for tree-maintenance requirements.

As expected, because both systems were supplied more nutrients than the crops needed, there were no significant differences in shoot length or trunk diameter between the organically and conventionally managed trees. Initial differences in trunk diameters between the two systems were maintained throughout the 4-year sampling period (data not shown).

\section{Fruit quality}

There was considerable cultivar and annual variation in fruit size and soluble solids (sweetness in degrees brix). However, there were no significant differences between the two systems for all 4 years and all cultivars combined. Crop load, which is known to influence fruit size and soluble solids, was affected by thinning method and apple scab. Scab reduced fruit number per tree in the organic system. Red Delicious, which was most af- fected by the disease, showed a significant increase in soluble solids content over the 4-year period in the organic system. In contrast, soluble solids decreased in Gravenstein and Golden Delicious (fig. 1E).

Fruit skin russet and bitter pit for all varieties combined did not differ significantly between the two systems (data not shown). Again, it varied considerably by variety and year between the organic and conventional treatments. Fruit in the organic system received no calcium sprays, while the conventional planting was sprayed three times per year, yet no real differences were observed. Organically grown Golden Delicious fruit were significantly less russeted, with $6.7 \%$ compared with $9.4 \%$ for the conventional treatment (fig. 1F). The Gravenstein fruit showed the same trend. The Red Delicious fruit, however, showed significantly more russet (29\%) in the organic treatment than in the conventional treatment (11.8\%). Red Delicious is very susceptible to skin russeting, especially when sprayed with sulfur-containing disease-prevention materials.

\section{Economic performance}

This study compared the economic performance of the two systems based on price per ton, yield per acre, returns per acre, and cultural costs per acre (table 5). In only one year, 1991, did the cooperator actually market fresh fruit on the organic market, taking advantage of a buoyant post-Alar demand. Although the higher price of the organic product initially suggests that the grower should have marketed

\begin{tabular}{|c|c|c|c|c|c|c|c|c|c|c|c|c|c|c|}
\hline & & \multirow{3}{*}{$\begin{array}{l}\text { Total N } \\
\text { April } \\
1991\end{array}$} & \multicolumn{6}{|c|}{ Ammonium- $\mathrm{N}\left(\mathrm{NH}_{4}-\mathrm{N}\right)$} & \multicolumn{6}{|c|}{ Nitrate-N $\left(\mathrm{NO}_{3}-\mathrm{N}\right)$} \\
\hline & & & April & May & April & May & June & April & April & May & April & May & June & April \\
\hline \multicolumn{2}{|c|}{ Treatment Depth } & & 1991 & 1991 & 1992 & 1992 & 1992 & 1993 & 1991 & 1991 & 1992 & 1992 & 1992 & 1993 \\
\hline \multicolumn{2}{|c|}{ inches } & $\%$ & \multicolumn{6}{|c|}{ ppm } & \multicolumn{6}{|c|}{. } \\
\hline \multirow[t]{3}{*}{ Conv. } & $0-6$ & 0.121 & 9.7 & 10.1 & 17.0 & 21.1 & 5.5 & $4.3^{\circ}$ & 3.5 & 9.4 & 13.2 & 52.6 & 72.1 & 7.3 \\
\hline & $6-12$ & 0.067 & 6.4 & 6.1 & 10.3 & $3.1^{\circ}$ & - & 4.6 & 4.3 & 6.9 & 8.0 & 61.4 & - & 6.9 \\
\hline & $12-18$ & 0.045 & 6.0 & 4.7 & 9.3 & 2.0 & - & 4.4 & 8.0 & 8.5 & 6.6 & 28.5 & - & 6.2 \\
\hline \multirow[t]{3}{*}{ Organic } & $0-6$ & 0.123 & 11.6 & 10.9 & 21.4 & 11.9 & 5.9 & 5.1 & 2.9 & 8.9 & $5.4^{*}$ & $25.4^{*}$ & $47.2^{* \prime}$ & 7.6 \\
\hline & $6-12$ & 0.062 & 7.0 & 7.8 & 12.9 & 13.3 & - & 4.7 & 3.3 & $4.0^{*}$ & $4.1^{\prime \prime}$ & 48.1 & - & 7.3 \\
\hline & $12-18$ & 0.036 & 6.8 & 12.1 & 13.0 & 11.3 & - & 4.0 & $5.3^{*}$ & $4.3^{* *}$ & $3.5^{* \prime}$ & 23.9 & - & 6.2 \\
\hline
\end{tabular}


his organic apples on the organic market, the grower decided that the greater effort required to market the organic product was not practical in light of his overall operation. The organic market requires sales and delivery to specific markets, certification procedures, separate packaging and special labeling. This experiment also represented a very small part of a large business that included a substantial brokerage operation, a trucking business and management of several conventional orchards. A grower with a smaller, more specialized operation might have chosen to market the organic fruit on the organic market each year.

For 1992 and 1993 we priced the organic fruit at market rates for juicers on the organic market, interpolating for the percentage of higher grade hand-picked juice and lower grade windfall juice apples. Quality evaluations indicated that the fruit, in general, would not have made peeler or fresh grades. 1990 was the transition year, so fruit could not have been sold organically.

Juice prices were used to calculate returns for the conventional fruit because that is how it was actually sold. Much of the conventional fruit, however, did make fresh market grade. It could have been sold at a higher price,

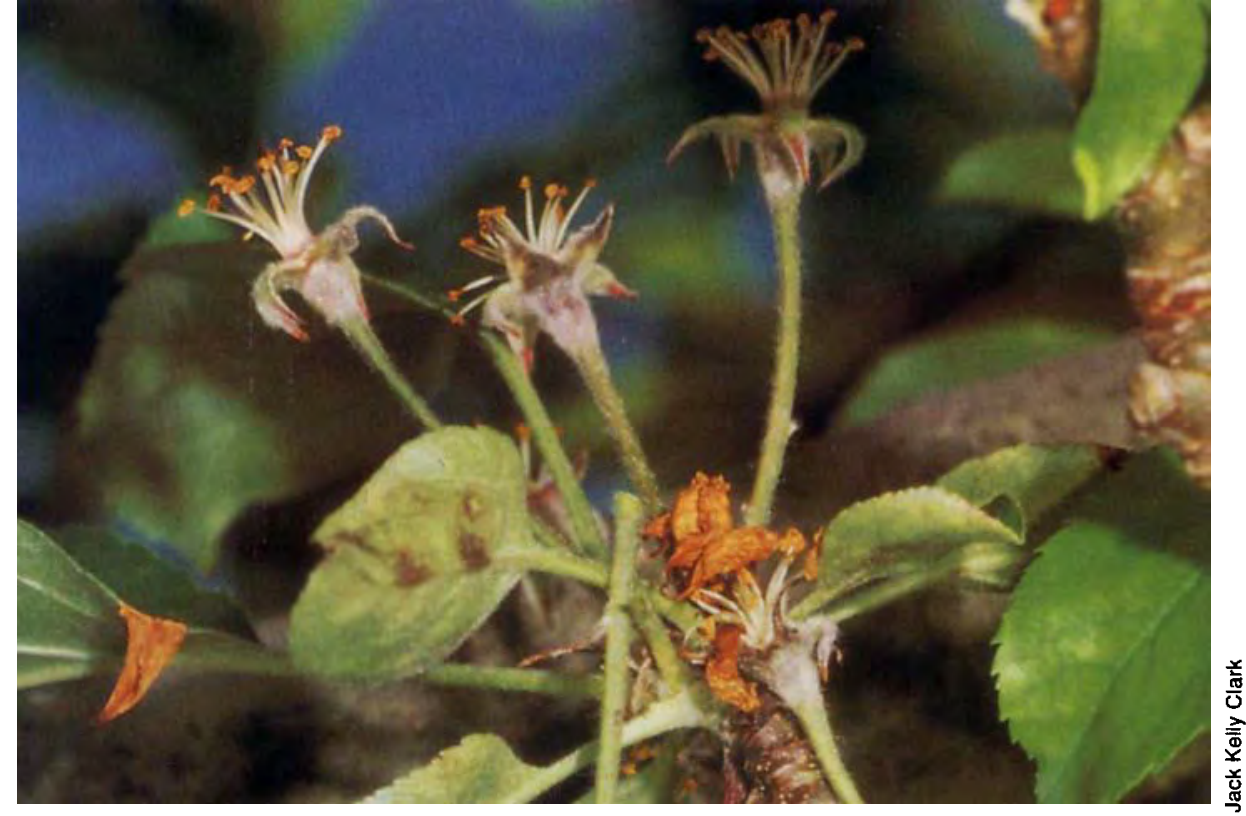

Early season scab infection caused blossom drop, which accounted for most of the yield loss.

but this was impractical in light of the entire operation.

We compared cultural costs and chose to ignore overhead and the interest costs on operating capital.

Equipment costs are priced at the market rates for custom operations, not at their actual costs.

As indicated in figure 1 and table 5, average yields for organic production over the trial period were significantly lower than for conventional production - approximately $30 \%$ lower for
Gravenstein, 54\% for Golden Delicious, and $35 \%$ for Red Delicious. If the costs of production had been equal, prices would have had to be that much higher to compensate for the lower yields. In most years, however, cultural costs per acre were actually higher on the organic acreage than on the conventional acreage, creating the necessity for larger differentials in favor of the organic product. Only in 1991 and 1992 was this kind of performance achieved.

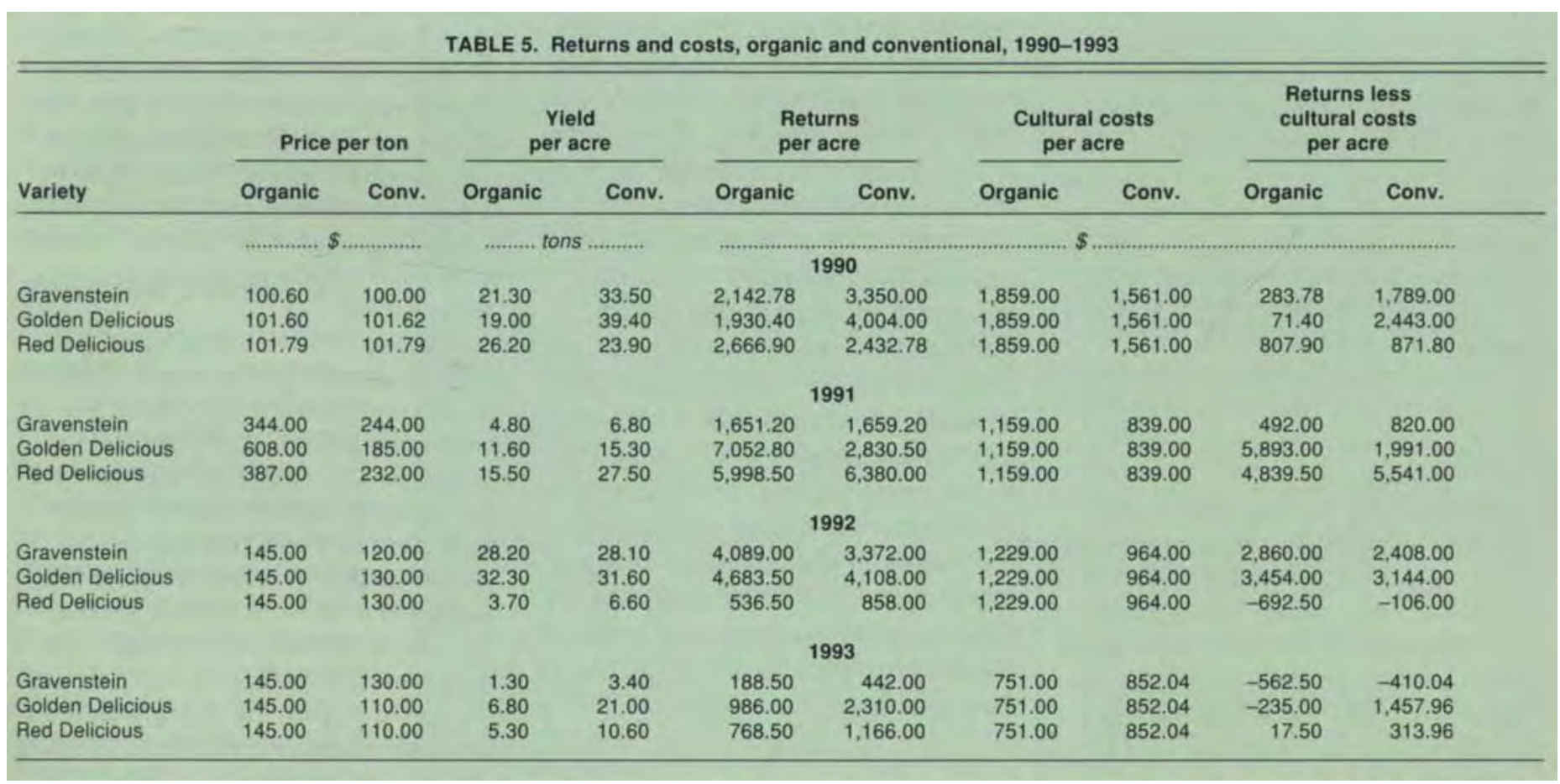


As shown in table 5, in 1992 organic Gravenstein and Golden Delicious outperformed their conventional counterparts by a small margin. Organic costs were higher due mainly to pest control operations. We should note, however, that protocols for pest and disease controls are not nearly as well defined for organic as for conventional production regimes.

Given the higher production costs, lower average yields and high variability in average yields and in quality, this trial suggests that the conventional system regularly outperforms the organic system. In the organic system, control of apple scab, codling moth and other pests was not adequate to obtain fresh market quality, except in 1991. If we had been successful in consistently controlling apple scab, codling moth and other pests, and in achieving fresh market quality, the economic performance of the organic system would have been radically changed. To some extent this occurred in 1991 and 1992 . Hence of 12 comparisons between organic and conventional returns over the 4-year trial, the conventional production system returned more than the organic production. Exceptions were in 1991, when organic fruit was sold on the fresh market, and in 1992, when organic yields compared very favorably with conventional yields. Note that in 1993, when yields dropped sharply, the organic system operated at a disadvantage even though less was expended on the organic acreage.

P. Vossen is Farm Advisor, Sonoma County Cooperative Extension; D. Jolly is CE Specialist, Department of Agricultural Economics, UC Davis; R. Meyer is CE Specialist, Land, Air and Water Resources, UC Davis; L. Varela is IPM Advisor, North Coast Counties; and $S$. Blodgett is former IPM Advisor, North Coast Counties.

We would like to thank George Jewell Jr. and Kate Burroughs for their help with this experiment. They would also like to acknowledge the funding sources of the UC Sustainable Agriculture Research and Education Program and the USDA Sustainable Agriculture Research and Education/Agriculture in Concert with the Environment Program.

\title{
In Santa Cruz County...
}

\section{Granny Smith conversions to organic show early success}

\author{
Sean L. Swezey $\square$ Jim Rider $\square$ Matthew R. Werner \\ Marc Buchanan $\square$ Jan Allison $\square$ Stephen R. Gliessman
}

Conventional and organic semidwarf Granny Smith apple production systems were compared during 3 years of conversion to certified organic management on California's Central Coast. Yields were significantly higher in the organic production system in 1989 and 1991 due to significantly greater fruit load. Growth indicators such as tree girth, terminal growth, leaf area, and so on, did not generally differ, but tissue levels of nitrogen were generally higher in leaf and new wood bark tissue in the conventional system, while phosphorus levels were generally higher in tissue of the organically managed trees. Key economic pest damage did not differ significantly in any year, although fruit and leaf damage due to some lepidopterous secondary pests was greater in some years in the conventional system. Apple leafhoppers showed significant increases in leaf damage in the organic system. Price premiums for organic apples consistently produced higher per-acre return for this system.
Making up a small but growing percentage of statewide acreage, certified organic apple production represents a potential alternative for California's conventional growers. Of over 30,000 acres used to cultivate apples in the state, between 1,500 and 2,000 acres are organic and in a certification program, according to growers' lists kept by California Certified Organic Farmers (CCOF), a major certification organization. This acreage has more than tripled since 1987, when fewer than 500 acres were certified statewide. In Santa Cruz County over 600 acres of apples are certified or in transition to organic certification. This increase in organic conversion rests heavily on the expanding market for certified organic apples for both fresh market and processing fruit.

Although conventional apple production systems in California are technically well documented, there is a nearly complete lack of published research on alternative management for the certified organic market, as presently defined by the California Organic Foods Act of 1990. Despite the increased interest in organic production, there has been little research on the agronomic and economic changes that occur during the conversion to organic management. We began to study this conversion process in April 1989, 